\title{
PEMANFAATAN DAN KARAKTERISTIK NORI TIRUAN MENGGUNAKAN BAHAN BAKU ALGA Hypnea saidana DAN UIva conglubata DARI PERAIRAN MALUKU
}

\section{UTILIZATION AND CHARACTERIZATION OF SINTHETIC NORI USING ALGAE Hypnea saidana AND Ulva conglubata FROM MOLLUCAS SEAWATER}

\author{
Vonda M. N Lalopua \\ Fakultas Perikanan dan Ilmu Kelautan Universitas Pattimura- Ambon, \\ Jl. Mr.Chr. Soplanit Kampus Poka- Ambon 97233, Tlp/Fax (0911)3825060/3825061 \\ E-mail : milcanite@gmail.com
}

Received : 08/12/2017; revised : 28/12/2017; accepted : 28/12/2017

Published online : 29/12/2017

\begin{abstract}
ABSTRAK
Perairan Indonesia tumbuh bemacam -macam spesies rumput laut dan berpeluang untuk memproduksi nori. Nori adalah makanan diet dari Jepang yang memiliki kandungan nutrisi tinggi. Kualitas nori tergantung dari warna nori. Penelitian bertujuan untuk mendeskripsi warna, mengetahui tingkat kesukaan dan kandungan kimia nori yang dibuat dari rumput laut Hypnea saidana, Ulva. conglubata dan kombinasi (H.saidana + U.conglubata). Metode penelitian yang digunakan adalah metode percobaan pembuatan nori menggunakan cuka apel untuk memperoleh jenis nori kualitas tinggi dilanjutkan dengan uji kesukaan sifat organoleptik dan analisa kandungan gizi. Hasil penelitian menunjukkan bahwa kualitas warna nori H.saidana lebih baik Panelis lebih suka akan warna nori U.conglubata sedangkan nori kombinasi lebih disukai dari rasa ,aroma dan kenampakan. Nori H.saidana memiliki kandungan air sebesar $29,57 \%$, abu $20,41 \%$, protein $1,36 \%$, serat kasar 4,09 \%, mineral kalsium 755,21 ppm dan besi 4,3 ppm
\end{abstract}

Kata kunci : Nori, Kandungan kimia, organoleptik

\begin{abstract}
It is generally accepted that various seaweed species grow well in Indonesian seawater which offers large opportunity for nori production.. Nori is a diet food from Japan with high nutritional content. Quality of the nori is depends on the colour of the nori. This study aimed to characterize the colour of nori, to investigate the taste and chemical content of nori made from seaweed Hypnea saidana, Ulva. conglubata and their combinations (H.saidana + U.conglubata). Here, nori is synthesized with the aid of apple vinegar to obtain high quality nori. In addition,characerization of nori was conducted through investigation of organoleptic properties as well as nutrien content analysis. The results showed that the colour quality of H.saidana nori was better than that made of U.conglubata. The panelist preferred the color of U.conglubata nori while the combination of nori was preferred from flavor, aroma and its appearance. Nori H.saidana has a water content of $29.57 \%$, ash $20.41 \%$, protein $1.36 \%$, crude fiber $4.09 \%$, calcium minerals $755.21 \mathrm{ppm}$ and iron $4.3 \mathrm{ppm}$
\end{abstract}

Key words: Nori, Chemical content, organoleptic

\section{PENDAHULUAN}

Rumput laut menjadi salah satu sumber devisa negara dan pendapatan terutama bagi masyarakat pesisir karena rumput laut adalah komoditi yang diperdagangkan secara domestik maupun internasional. Sebagai komoditi perdagangan, rumput laut telah dimanfaatkan secara luas sebagai sumber pangan, obatobatan serta bahan baku untuk industri (DKP 2007) Nori adalah olahan rumput laut alami yang dikeringkan dari rumput laut merah (Giury 2006). Nori merupakan makanan asli dari Jepang dari kelompok sayur-sayuran laut yang kaya akan sumber gizi: protein,mineral, serat kasar dan vitamin yang diperlukan tubuh. Nori juga mengandung beberapa asam amino penting seperti glutamat, glisin dan alanin yang berperan dalam menciptakan rasa nori serta mineral yodium yang dibutuhkan untuk fungsi normal kelenjar tiroid di dalam tubuh. Selain dikonsumsi langsung sebagai makanan ringan (snack), nori juga digunakan sebagai hiasan dan penyedap berbagai masakan. Nori dapat ditemukan di berbagai restoran China dan Jepang yang menyajikan menu siap saji maupun di swalayan 
dan toko bahan makanan yang menjual nori sebagai snack atau makanan ringan. Nori yang berkualitas tinggi biasanya berwarna hitam kehijauan, sedangkan nori berkualitas rendah berwarna hijau hingga hijau muda.

Nori merupakan sediaan berupa lembaran rumput laut yang dikeringkan dengan bahan baku adalah alga merah jenis Porphyra. Porphyra tidak terdapat dalam jumlah banyak di Indonesia karena Porphyra lebih cocok hidup pada iklim sub tropis. Berkembangnya restoran China dan Jepang yang menyajikan menu siap saji di Indonesia menyebabkan kebutuhan nori terus meningkat, demikian juga mulai ramainya makanan ringan snack yang dibuat dari nori menyebabkan kebutuhan nori di Indonesia semakin tinggi. Oleh karena itu perlu dicari alternatif bahan baku Porphyra. Beberapa jenis rumput laut yang dijadikan bahan baku pembuatan nori adalah Eucheuma cottonii dan rumput laut Cladophora yang sudah beradaptasi di laut. Beberapa hasil penelitian uji coba pembuatan nori menunjukkan bahwa Indonesia sangat berpeluang dalam memproduksi nori dari bahan baku yang tersedia diperairan Indonesia.

Perairan Indonesia memiliki berbagai macam jenis rumput laut, namun dari beragam jenis tersebut yang dimanfaatkan secara optimal, belum banyak bahkan yang dibudidayakan di pantai-pantai di Indonesia hanya terbatas pada jenis dari genus Eucheuma dan Gracillaria. Genus Hypnea adalah rumput laut dari kelompok alga merah (Rhodophyta), memiliki pigmen fikobilin yang terdiri dari fikosianin (warna biru) dan fikoeritrin (warna merah). Spesies Hypnea. saidana ditemukan tumbuh alami di perairan Pulau Haruku. Hypnea sp telah dimanfaatkan secara lokal sebagai bahan makanan (jajanan) berupa agar-agar atau dijual mentah dalam bentuk rumput laut kering. Hypnea adalah penghasil karagenan maupun agar dengan kandungan kimia berupa air sebesar $14-20 \%$, lemak $0,4 \%$, protein $16,1-22,5 \%$, serat 10,5 $13,5 \%$ dan mineral $3,5-8,5 \%$ (FAO 2008)

Ulva termasuk dalam kelompok alga hijau (Chlorophyta) dan di perairan Pulau Haruku ditemukan spesies U.conglubata. Ulva sp oleh para ahli dianggap sebagai sumber makanan yang sehat karena Ulva mengandung serat tinggi yang baik bagi pencernaan, dan memiliki kandungan kimia berupa kadar air 18,7\%, protein $14,9 \%$, lemak $0,04 \%$, karbohidrat $50,6 \%$ dan serat $0,2 \%$. Ulva adalah sumber vitamin C, asam folat dan beberapa jenis mineral seperti $\mathrm{Ca}, \mathrm{K}, \mathrm{Mg}, \mathrm{Na}, \mathrm{Cu}$, Fe dan Zn. (Anggadiredja dkk 2006). Ulva telah dikonsumsi sebagai salad atau sup. Baik H.saidana maupun U.conglubata belum dimanfaatkan oleh masyarakat di Maluku dan ke dua rumput laut ini berpotensi sebagai bahan baku alternatif untuk mengganti Porphyra sp.

Tujuan Penelitian untuk Mengetahui kualitas warna nori, kesukaan akan sifat organoleptik dan kandungan kimia nori dari bahan baku alga $H$. saidana, U. conglubata dan kombinasi $H$. saidana dan $U$. Conglubata.

\section{METODE PENELITIAN}

\section{Bahan Penelitian}

Bahan baku yang digunakan dalam pembuatan nori adalah alga merah $H$. saidana dan U.conglubata diperoleh dari perairan Hulaliu Pulau Haruku, cuka apel serta alumunium foil. Bahan kimia yang digunakan 1-2 $\mathrm{ml} \mathrm{HNO}_{3}, \mathrm{HgO}$, $\mathrm{NaOH}$ pekat, asam klorida, $\mathrm{HCl}$, aquades, asam nitrat pekat dan asam perklorat pekat.

\section{Alat Penelitian}

Peralatan yang digunakan dalam penelitian ini adalah baskom, saringan, blender, micrometer/penggaris, Erlenmeyer $600 \mathrm{ml}$, gelas ukur $(100 \mathrm{ml}, 250 \mathrm{ml}, 800 \mathrm{ml})$, sendok pengaduk, pompa vakum, pisau, sendok makan, untuk pembuatan nori. Peralatan untuk pengujian nilai gizi nori meliputi : cawan (stainless steel, alumunium atau porselen, desikator, krus porselen, penjepit cawan, penggiling, furnace, timbangan analitik, hot plate, tanur pengabuan, soxhlet dan oven.

Metode yang digunakan dalam penelitian adalah metode eksperimen. Penelitian ini terdiri dari 2 tahap. Tahap 1. Pembuatan nori, dilanjutkan dengan deskripsi warna serta uji kesukaan sifat organoleptik nori : warna,rasa,bau dan tekstur. Tahap 2. Analisa kandungan kimia nori. Nori yang dianalisis adalah nori yang memiliki kualitas warna terbaik.(deskripsi warna secara subjektif oleh 3 orang panelis terlatih menggunakan nori komersial sebagai pembanding). Uji kesukaan sifat organoleptik nori, warna, rasa, aroma dan kenampakan/tekstur dilakukan oleh 15 panelis menggunakan score sheet skala 1-9.

\section{Perlakuan}

adalah spesies :

Variabel perlakuan yang digunakan

1. H.saidana $\left(\mathrm{A}_{1}\right)$

2. U.conglubata $\left(\mathrm{A}_{2}\right)$

3. Kombinasi H.saidana dan U.conglubata $\left(A_{3}\right)$

\section{Prosedur Pembuatan nori}

Prosedur pembuatan nori tiruan menggunakan metode Teddy (2009) yang dimodifikasi, dengan cara sbb : Rumput laut $H$.saidana dan $U$. conglubata, dicuci dengan air 
laut kemudian dibilas dengan air tawar mengalir hingga bersih. Alga masing-masing ditimbang sebanyak $100 \mathrm{gr}$ (untuk nori kombinasi menggunakan @ 0 gram). Bumbu yang digunakan adalah bawang putih halus (1 sendok makan), merica secukupnya dan penyedap rasa (masako) (1 sendok makan) serta ditambahkan cuka apel sebanyak $5 \mathrm{ml}$, air $100 \mathrm{ml}$ (sesuai perlakuan) setelah itu dihaluskan dengan cara diblender dan direbus selama \pm 15 menit hingga mengental. Selanjutnya rumput laut yang sudah dimasak dituang dalam cetakan dan dikeringkan di dalam dioven menggunakan oven vakum selama 1 jam pada suhu $150^{\circ} \mathrm{C}$.

\section{Prosedur Analisa \\ Kadar Abu (AOAC 1984)}

Sampel ditimbang sebanyak 1-5 gram, lalu dimasukkan ke dalam cawan porselen yang sudah diketahui bobot tetapnya. Sampel dibakar di atas bunsen dengan nyala api kecil hingga berasap, selanjutnya dimasukkan ke dalam tanur pada suhu $500-600{ }^{\circ} \mathrm{C}$ sampai menjadi abu yang berwarna putih. Cawan yang berisi abu didinginkan dalam desikator dan dilakukan penimbangan hingga diperoleh bobot tetap.

Kadar abu dapat dihitung dengan rumus.

$$
\% \text { kadar abu }=\frac{\text { Berat abu }(g)}{\text { Berat sampel }(g)} \times 100 \%
$$

\section{Kadar Air (SNI 01.2354.2-2006)}

Oven dikondisikan pada suhu yang akan digunakan hingga mencapai kondisi stabil, kemudian dimasukkan cawan kosong ke dalam oven minimal 2 jam. Cawan kosong tersebut dipindahkan ke dalam desikator sekitar 30 menit sampai mencapai suhu ruang, lalu ditimbang bobot cawan kosong (A). Ditimbang sebanyak \pm $2 \mathrm{~g}$ contoh ke dalam cawan (B). Cawan yang telah berisi contoh dimasukkan ke dalam oven tidak vakum pada suhu $105^{\circ} \mathrm{C}$ selama $16-24$ jam. Cawan dipindahkan ke dalam desikator selama \pm 30 menit dengan menggunakan penjepit, kemudian ditimbang (C).

$$
\% \text { kadar air }=\frac{B-C}{B-A} \times 100 \%
$$

Keterangan :

$\mathrm{A}=$ berat cawan kosong, dalam gram

$\mathrm{B}=$ berat cawan + contoh awal, dalam gram

$\mathrm{C}=$ berat cawan + contoh kering dalam gram

\section{Kadar serat kasar ( SNI 1992 01-2891)}

Timbang seksama 2 - 4 gram cuplikan. Bebaskan lemaknya dengan cara ekstraksi dengan metode Soxhlet atau dengan cara mengaduk. Kemudian endapkan contoh dalam pelarut organik sebanyak 3 kali. Keringkan contoh dan masukkan kedalam erlenmeyer 500 ml. setelah itu tambahkan $50 \mathrm{ml}$ larutan $\mathrm{H}_{2} \mathrm{SO}_{4}$ $1,25 \%$, didihkan selama 30 menit dengan menggunakan pendingin tegak. Tambahkan 50

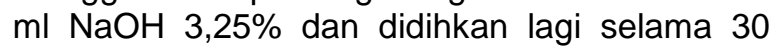
menit. Dalam keadaan panas, saring dengan corong buser yang berisi kertas saring whatman 54,41 atau 541 yang telah dikeringkan dan diketahui beratnya. Cuci endapan yang terdapat pada kertas saring berturut - turut dengan $\mathrm{H}_{2} \mathrm{SO}_{4} 1,25 \%$ panas dan etanol $96 \%$. Angkat kertas saring beserta isinya masukan kotak limbang yang telah diketahui berat atau bobotnya. Keringkan pada suhu $105^{\circ} \mathrm{C}$, dinginkan sampai - sampai bobot tetap. Bila ternyata kadar lebih besar $1 \%$, abukan kertas saring beserta isinya dan timbang sampai bobot tetap.

Perhitungan :

$$
\text { Kadar serat kasar (\%) }=\frac{w 2-w 1}{w} \times 100 \%
$$

Dimana $: \mathrm{w}=$ bobot cuplikan, dalam gram

$\mathrm{W}_{1}$ = bobot abu, dalam gram

$\mathrm{W}_{2}$ = bobot endapan, dalam gram

\section{Analisis kadar protein}

\section{Destruksi}

Kedalam labu kjeldhal $300 \mathrm{ml}$ masukkan sampel sebanyak 1-2 gram ditambahkan dengan campuran 3 gram destruksi dan $20 \mathrm{ml}$ asam sulfat pekat. Panaskan labu tersebut dalam tungku pemanas, hingga warna larutan yang semula hitam berubah menjadi warna jernih. Selama pemanasan, ujung labu Kjeldhal dipasang corong untuk mencegah keluarnya larutan $\mathrm{H}_{2} \mathrm{SO}_{4}$ pekat. Setelah selesai destruksi, dinginkan labu Kjeldhal, kemudian permukaan labu tersebut dibilas dengan aquades dan larutan dicampur sampai homogen.

\section{Destilasi}

Setelah aquades mendidih dalam labu 20 $\mathrm{ml}$, masukkan secara kuantitatif larutan sampel pada hasil destruksi ke dalam labu melalui corong dan tiga tetes indicator phenolphthalein. Pasang larutan penampung kedalam gelas piala $300 \mathrm{ml}$ berisi ( $50 \mathrm{ml}$ larutan $2 \%$ asam borat dan 5 tetes indicator tashiro) dibawah ujung pendingin dimana ujungnya tercelup kedalam larutan penampung. 
Tuangkan secara bertahap larutan $\mathrm{NaOH}$ pekat melalui corong sampai larutan sampel dalam labu bersifat alkalis. Alirkan uap panas kedalam labu dengan cara membuka kran. Destilasi diakhiri bila destilat yang menetes diujung kolom labu dengan aquades berulang-ulang sampai bersih.

\section{Titrasi}

Perhitungan : pendingin bereaksi netral terhadap lakmus merah.Warna larutan penampung menjadi hijau, untuk mengeluarkan larutan sampel pada labu, pertama-tama tutup kran sehingga uap panas mengalir kearah vertikal dan buka kran. Cuci Titrasi larutan penampung dengan larutan 0,1 N $\mathrm{HCl}$ hingga warna larutan kembali menjadi merah muda (pink).

Kadar protein $(\%)=\frac{(\text { Ml tritasi } \mathrm{HCl} \times \mathrm{N} \mathrm{HCl}) \times 14 \times 62,5}{1000 \times \text { Berat Sampel }(g)} \times 100 \%$

\section{Analisa Data}

Data yang diperoleh merupakan nilai rata-rata dari 3 ulangan analisis, sehingga diperoleh 9 sampel. Metode indeks efektivitas digunakan untuk penentuan nori tiruan terbaik hasil uji kesukaan sifat organoleptik. Data yang diperoleh dianalisis secara deskriptif dan hasilnya disajikan pada tabel dan gambar.

\section{HASIL DAN PEMBAHASAN}

\section{Deskripsi Warna}

Tabel 1 menunjukkan hasil deskripsi warna dan tingkat kesukaan nori tiruan dari $H$. saidana, $U$. conglubata dan kombinasi. $H$. saidana $+U$. conglubata.

Tabel 1. Deskripsi Warna .dan Tingkat Kesukaaan Panelis Terhadap Nori Tiruan

\begin{tabular}{|c|c|c|c|c|c|}
\hline \multirow[t]{2}{*}{ Rumput laut } & \multirow[t]{2}{*}{ Warna Nori } & \multicolumn{2}{|r|}{ Tingkat } & kesukaan & \multirow[b]{2}{*}{$\begin{array}{l}\text { Kenampakan } \\
\text { Tekstur }\end{array}$} \\
\hline & & Warna & Rasa & Aroma & \\
\hline H. saidana & Hijau cokelat tua & 6,60 & 6,13 & 5,80 & 5,47 \\
\hline U. conglubata & Hijau muda & 5,53 & 5,73 & 5,13 & 5,53 \\
\hline $\begin{array}{l}H \text { saidana }+U . \\
\text { conglubata }\end{array}$ & Hijau kecoklatan & 5.73 & 6,20 & 5,93 & 5,8 \\
\hline
\end{tabular}

Warna nori tiruan dari rumput laut $H$. saidana adalah hijau cokelat tua, sekilas hampir mirip warna nori kombinasi, warna hijau kecoklatan (Gambar 1). Sedangkan nori $U$. conglubata berwarna hijau muda. Hasil penelitian menunjukkan bahwa kualitas warna nori $H$. Saidana lebih tinggi dari nori yang lain. Kualitas nori ditunjukkan oleh warna dimana lembaran nori berkualitas tinggi biasanya berwarna hitam kehijauan dan nori berkualitas rendah berwarna hijau - hijau muda (FAO 2008) Secara keseluruhan warna nori belum merata, terdapat bagian dengan warna lebih tua dari bagian lainnya, tampak jelas pada nori kombinasi. Warna nori yang tidak merata disebabkan oleh kurangnya pengadukan/pencampuran larutan dengan baik sebelum dituang ke dalam cetakan. Warna nori sangat tergantung dari warna pigmen alga yang digunakan. Nori tiruan dari $U$. conglubata berwarna hijau muda mirip warna rumput laut $U$. conglubata demikian pula warna nori $H$. saidana merah coklat tua mirip warna rumput laut $H$. Saidana, sedangkan warna nori kombinasi merupakan hasil pencampuran pigmen alga hijau dan merah tua menghasilkan warna merah kecoklatan. Warna nori sangat dipengaruhi oleh waktu dan suhu pengeringan, warna nori tiruan lebih baik dari nori dari Noya (2015), warna nori berubah menjadi cokelat setelah dijemur matahari selama 8 - 12 jam.

Pada semua alga terdapat klorofil, pigmen yang larut dalam lemak. Kandungan klorofil pada alga coklat adalah $5-2000 \mathrm{mg} / \mathrm{kg}$ $\%$ bk. Selain klorofil, terdapat pula pigmen karotenoid. Karotenoid adalah tetraterpen, sedangkan karoten adalah hidrokarbon. Spesies alga hijau mengandung Beta karoten, lutein, violaxhantin, neoxanthin dan zeaxanthin sedangkan alga merah kebanyakan mengandung beta karoten, lutein dan zeaxhantin (Haugan and Jensen 1994 dalam Holdt dan Kraan 2011). Hypnea sp mengandung pigmen fikoeritrin dalam jumlah cukup banyak dibandingkan dengan kandungan pigmen klorofil, karoten dan xantofil sedangkan Ulva mengandung klorofil yang terdapat dalam kloroplas bersama dengan karoten dan xantofil.

Warna nori Jepang yaitu hitam kehijauan disebabkan oleh kandungan klorofil a dan phycobilin yang terdapat dalam kloroplas bersama sama dengan karoten dan xantofil 
(Nisizawa 2002). Hypnea sp mengandung pigmen fikoeritrin dalam jumlah cukup banyak dibandingkan dengan kandungan pigmen klorofil, karoten dan xantofil sedangkan Ulva mengandung klorofil yang terdapat dalam kloroplas bersama dengan karoten dan xantofil.

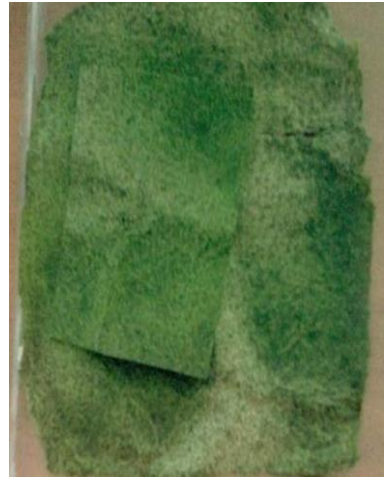

1

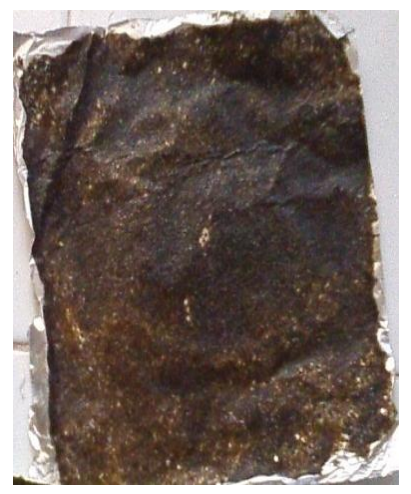

2

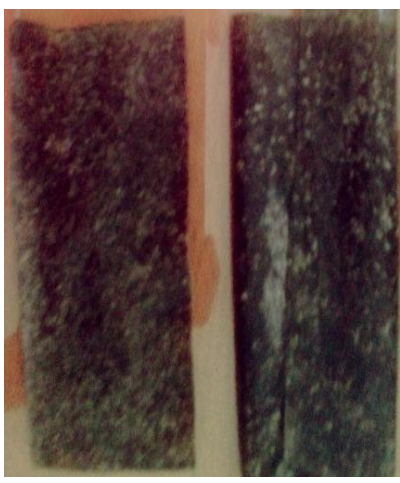

3

Gambar 1. Contoh Produk Nori Tiruan (1. Ulva, 2. Hypnea saidana. 3 kombinasi).

\section{Kesukaan Sifat Organoleptik Nori}

Tabel 1, menunjukkan bahwa kesukaan panelis terhadap warna, aroma dan tekstur nori tiruan berkisar pada nilai $5-7$, nilai $5=$ biasa , 6 $=$ Agak suka, 7 = suka. Warna nori $U$. conglubata lebih disukai panelis $(6,6)$ daripada nori $H$. saidana $(5,53)$ dan nori kombinasi $(5,73)$. Kesukaan panelis terhadap nori $U$. conglubata diduga karena warnanya hijau segar menyerupai warna rumput laut jadi lebih menarik dari pada wana hijau kehitaman dan hijau kecoklatan. Diduga bahwa panelis yang melakukan uji kesukaan belum mengenal atau mengkonsumsi nori. Waysima dkk, (2010) menyatakan daya tarik suatu produk adalah warna, dengan melihat warna konsumen dapat menangkap kesan tertentu terhadap rasa

Nori kombinasi lebih disukai untuk rasa, aroma maupun kenampakan/tekstur. Rasa nori tiruan adalah gurih karena ditambah bumbu. Rasa nori dipengaruhi komponen asam amino yang bersumber dari rumput laut dan bumbu yang digunakan. Kombinasi asam amino dari rumput laut dan bumbu memberi kontribusi terhadap nilai rasa maupun aroma nori.
Beberapa asam amino bebas (asam glutamat,glisin, serin,lisin, valin, serin,theonin dII) berkontribusi terhadap karakteristik rasa pada makanan (manis, pahit atau asam). Karakteristik rasa nori disebabkan oleh tingginya kandungan 3 asam amino yaitu asam glutamat, sistein dan alanin (McHugh 2003). Ulva sp mengandung sejumlah besar asam amino sisteinolik, asam sisteik, praline,asam glutamat dan chondrine.

Kenampakan nori tiruan adalah permukaan pori cukup rapat dan rata dan tekstur nori tidak mudah hancur. Tekstur yang baik ini dapat diperoleh dengan penggunaan cuka apel dapat memperoleh tekstur yang rapat menyerupai nori komersil. Tekstur nori lebih baik dari hasil penelitian Noya (2015). Berdasarkan hasil deskripsi warna maka warna nori tiruan terbaik adalah nori $H$. saidana, sedangkan hasil organoleptik nori yang dianalisis dengan metode indeks efektivitas, yang terbaik 1 (rangking 1) adalah nori $U$. conglubata dan terbaik 2 (rangking 2) adalah nori kombinasi. Nori $H$. Saidana dengan kualitas tinggi dianalisis kandungan gizinya, Kandungan gizi Nori $H$. saidana disajikan pada Tabel 2.

Tabel 2. Kandungan Gizi Nori $H$. saidana

\begin{tabular}{ccccccc}
\hline Hasil uji & $\begin{array}{c}\text { Kadar air } \\
(\%)\end{array}$ & $\begin{array}{c}\text { Kadar abu } \\
(\%)\end{array}$ & $\begin{array}{c}\text { Kadar } \\
\text { protein } \\
(\%)\end{array}$ & $\begin{array}{c}\text { Kadar serat } \\
\text { kasar (\%) }\end{array}$ & $\begin{array}{c}\text { Kadar Ca } \\
(\mathbf{p p m})\end{array}$ & $\begin{array}{c}\text { Kadar Fe } \\
\text { (ppm) }\end{array}$ \\
\hline $\begin{array}{c}\text { Ulangan } \\
\quad\end{array}$ & 29,57 & 19,74 & 1,36 & 4,11 & 729,49 & 4,2 \\
$\begin{array}{c}\text { Ulangan } \\
2\end{array}$ & 29,56 & 21,08 & 1,37 & 4,07 & 780,92 & 4,4 \\
Rata-rata & 29,57 & 20,41 & 1,36 & 4,09 & 755,21 & 4,3 \\
\hline
\end{tabular}

Kadar air

Kadar air nori $H$. saidana sebesar

$29,57 \%$, lebih tinggi dari kadar air nori dari
Porphyra sp, $16,09 \%$ maupun nori dari Gracillaria sp, 17,17 \% (Teddy 2009). Kadar air mempengaruhi kerenyahan nori. Semakin 
rendah kadar air, semakin tinggi kerenyahan nori dan sebaliknya semakin tinggi kadar air, semakin rendah kerenyahan nori. Andarwulan dkk (2011) menyatakan bahwa air dalam bahan pangan dihubungkan dengan mutu bahan pangan sebagai penentu mutu organoleptik terutama rasa dan kerenyahan.

Nori merupakan lembaran rumput laut yang dikeringkan atau dipanggang (Korringa 1976 dalam Teddy 2009). Nori digunakan untuk membungkus bola atau gulungan nasi atau diiris menjadi strip tipis dan ditaburkan di atas makanan sebagai bumbu berbagai masakan. (Shiokawa 2008). Nori dapat dikonsumsi langsung sebagai makanan ringan (snack), nori juga digunakan sebagai hiasan dan penyedap berbagai macam masakan Jepang, misalnya pemberi rasa pada pengolahan mie dan sup serta lauk sewaktu makan nasi dan biasanya ditambahkan ke dalam makanan ringan dan renyah seperti senbei. Senbei adalah makanan ringan yang renyah atau disebut juga crackers berbentuk bulat dan pipih.

Nori umumnya dikemas dalam kemasan kantong plastik, botol plastik atau kaleng kedap udara karena sifat nori yang mudah kehilangan rasa renyah dan mudah menjadi lembab. Ajitsuke nori (okazu nori) adalah nori yang lebih mudah menjadi lembab dibandingkan nori biasa, oleh sebab itu ajitsuke nori biasanya dikemas dalam bungkusanbungkusan kecil yang hanya berisi beberapa lembar nor berukuran mini. Ajitsuke nori atau okazunori adalah satu lembar nori standar yang sudah diberi bumbu garam dapur, kecap asin, gula atau mirin dipotong menjadi 8 atau 12 potongan kecil. Ajitsuke nori umumnya dimakan sebagai teman makan nasi sewaktu sarapan pagi atau dimakan begitu saja sebagai makanan ringan. Walaupun diberi kemasan, namun nori banyak menggunakan gel silika dan bahanbahan lain sebagai penyerap kelembaban.

\section{Kadar abu}

Kadar abu dari suatu bahan menunjukkan kandungan mineral yang terdapat dalam bahan. Kadar abu total adalah bagian dari analisis proksimat yang digunakan untuk mengevaluasi nilai gizi suatu bahan pangan (Andarwulan dkk 2011). Kandungan abu alga laut terdiri atas makro mineral dan trace elemen. Abu pada alga laut sebagian besar terdiri atas polisakarida sebagai pembentuk struktur sel, mycopolisakarida dan polisakarida penyimpan (Kumar et al 2008). Kadar abu alga laut dikenal sangat tinggi telah dimanfaatkan untuk pakan dan suplemen pangan sebagai sumber mineral. Kandungan mineral alga laut 10-100 kali lebih tinggi dari sayuran (Arasaki Arasaki 1993 dalam Holdt dan Kraan 2011).
Kadar abu/mineral pada alga dapat mencapai $50 \%$ bk. Beberapa mineral alga dibutuhkan tubuh untuk kesehatan tetapi ada jenis mineral yang bersifat toksik dengan tingkatan yang bervariasi. Komposisi mineral bervariasi tergantung pada phylum alga, dipengaruhi oleh musim,kondisi lingkungan, variasi geografis dan fisiologi. Mineral yang sangat penting dari alga laut adalah yodium, umumnya kandungan yodium pada alga merah lebih tinggi dari alga hijau dan alga cokelat dan kandungan yodium alga bersifat konstan (Mabeau and Fleurence 1993).

Kadar abu nori $H$. saidana sebesar $20,41 \%$. Hasil ini lebih tinggi dari kadar abu Porphyra sp 5,12\% dan nori dari Gracillaria sp $4,36 \%$ (Teddy 2009) Kandungan mineral Hypnea sp 3,5-8,5\% (McHugh 2003). Kadar abu nori dipengaruhi spesies alga sedangkan kadar abu spesies alga dipengaruhi oleh bentuk penanganan dan pengolahan, habitat, rumput laut, spesies, umur panen, variasi musim dan variasi fisiologis rumput laut.

\section{Kadar protein}

Nori merupakan salah satu makanan yang memiliki kandungan nutrisi tinggi. Kandungan protein nori mencapai $25-50 \%$ berat kering, (Kayama et al 1985 dalam Murdinah 2007). Nilai gizi nori bervariasi, contohnya dari $100 \mathrm{~g}$ kering yaki - nori mengandung $41,4 \mathrm{~g}$ kadar protein dan $3,7 \mathrm{~g}$ kadar lemak, Kadar protein nori H. saidana sebesar $4,09 \%$, kadar protein nori tiruan ini lebih rendah dari nori Porphyra sp 6,15 $\%$ dan Gracillaria sp, 6,84 \% (Teddy 2009). Fraksi protein alga bervariasi dengan spesies alga dimana kandungan protein alga hijau dan merah lebih tinggi dari alga cokelat. Kandungan protein Hypnea berkisar 16,1-22,5\% (McHugh 2003). Rendahnya kadar protein nori $H$. Saidana dapat disebabkan oleh kelarutan protein yang dipengaruhi oleh perubahan $\mathrm{pH}$ karena penggunaan cuka apel. Perubahan $\mathrm{pH}$ mempengaruhi ionisasi gugus fungsional protein sehingga muatan total protein berubah. Pada titik isoelektrik, total muatan protein sama dengan 0 sehingga interaksi antar molekul protein menjadi maksimum. Pada kondisi ini,protein mencapai titik isoelektriknya dan memiliki kelarutan minimum. Kelarutan protein adalah persen dari total protein yang terdapat di dalam bahan pangan yang dapat diekstrak atau larut dalam air pada kondisi tertentu.

Umumnya protein alga mengandung semua asam amino esensial dan kaya akan asam amino asam seperti asam aspartat dan asam glutamat. Threonin, glisin, triptophan, sistein, metionin, histidin merupakan asam amino pembatas pada alga, meskipun demikian kandungan protein alga jauh lebih tinggi dari 
tanaman darat (Galland Irmouli 1999 ) Kadar protein alga merah kaya akan kandungan asam amino asam : asam glutamat dan dan asam aspartat namun rendah akan kandungan asam amino basa. Beberapa penelitian melaporkan bahwa asam aspartat dan asam glutamat pada alga merah rendah (Fleurence 2004). Habitat dan spesies alga sangat berpengaruh terhadap kadar protein dan komposisi asam amino alga (Dawezynski et al 2007).

\section{Kadar serat kasar}

Total serat pangan dalam edible seaweed berkisar $33-62 \% \mathrm{db}$, lebih tinggi dari serat pangan tanaman. Serat pangan edible seawed terutama terdiri dari fraksi serat yang larut (Lahaye 1991 dalam Holdt dan Kraan 2011). Dietary fibre seaweed terdiri atas fraksi yang larut : Agar, asam alginat,laminaran dan porphyran dan fraksi tak larut : selulose, manan dan xylan. Mayoritas kandungan serat dalam edible seaweed adalah polisakarida anionik yang larut, bersifat kurang terdegradasi atau tidak terfermentasi oleh mikroflora pada usus besar manusia (Lahaye dan Kaeffer,1997 dalam Holdt dan Kraan 2011). Kandungan serat makanan dalam nori dan wakame dapat mencapai $34 \%$ berat kering (FAO 2008). Serat adalah non gizi, ada dua jenis serat yaitu serat makanan (Dietary Fiber) dan serat kasar (Crude Fiber). Serat kasar merupakan residu dari bahan makan yang telah diperlakukan dengan asam dan alkali mendidih, dan terdiri dari selulose dengan sedikit lignin dan pentose. Serat kasar ialah sisa-sisa bahan makanan yang telah mengalami proses pemanasa dengan asam kuat dan basa kuat. Dengan proses seperti ini dapat merusak beberapa komponen atau macam serat yang tidak dapat dicerna oleh manusia dan tidak dapat diketahui komposisi-komposisi kimia tiap-tiap bahan yang membentuk dinding sel. Oleh karena itu serat kasar merendahkan perkiraan jumlah kandungan serat sebesar 50-90 \% untuk lignin dan $20-50 \%$ untuk selulosa. Kandungan selulose dan hemiselulose pada alga masing-masing 2-10 $\%$ dan $9 \%$ bk. Lignin hanya ditemukan pada Ulva sp sebesar $3 \%$ bk.

Kadar serat kasar nori $H$. saidana 4,09 $\%$. Kadar serat $H$. saidana segar dilaporkan oleh Mc Hugh (2003) sebesar 10,5 - 13,5\%. Makanan dengan kandungan serat kasar relatif tinggi biasanya mengandung kalori rendah, kadar gula dan lemak yang rendah pula yang dapat mencegah obesitas dan penyakit jantung (Anonymous 2008). Makanan dengan kandungan serat kasar yang tinggi dilaporkan dapat mengurangi berat badan. Peran utama dari serat dalam makanan adalah pada kemampuannya mengikat air, selulosa dan pektin. Dengan adanya serat dapat membantu mempercepat sisa-sisa makanan melalui saluran pencernaan untuk diseksresikan keluar. Tanpa bantuan serat, feses dengan kandungan air rendah akan lebih lama tinggal dalam saluran usus dan mengalami kesukaran melalui usus untuk dapat dieksresikan keluar karena gerakangerakan peristalik usus besar menjadi lebih lambat (Nurbahri 2010).

\section{Kadar Mineral kalsium dan besi Nori}

Tidak semua mineral yang yang terdapat pada bahan pangan dibutuhkan untuk pertumbuhan tubuh. Jenis mineral yang dibutuhkan tubuh antara lain adalah mineral kalsium dan besi. Kalsium berperan sebagai pembentuk dan pemelihara tulang dan gigi. Kalsium yang berada dalam sirkulasi darah dan jaringan tubuh berperan dalam transmisi, impuls syaraf, kontraksi otot, penggumpalan darah, pengaturan permeabilitas membrane serta membantu reaksi enzimatis. Kekurangan kalsium dalam tubuh dapat menyebabkan osteomalasia, yang ditandai dengan pelunakan tulang. Kekurangan kalsium juga menyebabkan kerapuhan tulang, pertumbuhan lambat dan kerusakan gigi serta depresi.Tabel 2 menunjukkan bahwa kadar kalsium nori $H$. saidana sebesar 755,21 ppm dan kadar besi 4,3 ppm. Kadar kalsium dan besi nori tiruan dipengaruhi oleh jenis rumput laut. Mc Hugh (2003) melaporkan bahwa kadar mineral rumput laut $H$. saidana sebesar 4-5\%. Kadar kalsium rumput laut sekitar 4-7 \% dari berat kering atau sekitar 4000-7000 mg/100 g berat kering sedangkan kadar kalsium alga merah sebesar 200-300 mg/100 g berat kering.

Mikro mineral yang terkandung dalam talus rumput laut adalah besi. Fungsi utama besi adalah bersama-sama dengan protein dan tembaga membentuk sel darah merah (hemoglobin). Besi juga meningkatkan kualitas darah dan meningkatkan ketahanan terhadap stress dan penyakit. Besi penting bagi pembentukan myoglobin yang terdapat pada otot. Defisiensi zat besi dapat menyebabkan anemia serta konstipasi.

\section{KESIMPULAN}

Nori tiruan berbeda warna satu dengan yang lain yaitu hijau coklat tua, hijau muda dan hijau kecoklatan. Ukuran nori tiruan $20 \times 15 \mathrm{~cm}$, berat 2-3 g, ketebalan $1 \mathrm{~cm}$. Permukaan nori cukup rapat dan rata dengan pori kecil dan tidak mudah hancur. Nori dari bahan baku $U$. conglubata dan kombinasi (H.saidana+ $U$. Conglubata) lebih disukai sifat organoleptik warna, rasa,aroma, kenampakan serta tekstur tetapi nori $H$. saidana memiliki kualitas warna lebih baik dengan kandungan kimia: air 29,57\% 
, abu $20,41 \%$, protein $1,36 \%$, serat kasar 4,09 $\%$, mineral kalsium 755,21 ppm dan besi Fe 4,3 ppm

\section{DAFTAR PUSTAKA}

Anggadiredja, T. 2006. Rumput Laut. Penerbit Penebar Swadaya : Jakarta.

Anonimous. 2008. Division Rhodphyta (red algae).

http;//lifeinkochi.net/2010/07Asakusanori -porphyra-tenera-kjellman. Diakses 15 Oktober 2017

Andarwulan, N., Kusnandar, F. dan Herawati, D. 2011. Analisis Pangan. Dian Rakyat

DKP. 2007. Rumput laut. Dinas Kelautan dan Perikanan. Diakses Agustus 2006

Dawezynki, C Rainer S, Gerhard J. 2007. Amino acids, fatty acids, and dietary fibre in edible seaweed product. J.Food.Chem 103: $891-899$

FAO. 2008. Nori.www.fao.org. Diakses September 2008.

Fleurence, J. 2004. Seaweed proteins InYada Ry (ed) Poteins in food processing. Woodhead Publishing Cambridge. Pp, 197-213

Galland Irmoumoulli, AV., Fleurence,J., Langhari,R., lucon,M. 1999. Nutritional value of proteins from edible seaweed Palmaria palmata (dulse). J. Nutr.Biocem 10 : 353-359.

Giury. 2006. The Irish seaweed industry.:Http//www.seaweed.ie/algae.H mtl. Diakses : 26 september.

Holdt, S and Kraan, S. 2011. Bioactive compound in seaweed: Functional food application and legislation. J.appl.phycol DOI 10.1007/s10811-010-9632-5.

Kumar, K., Suresh, K., Ganesan, P. V. and Rao, S. 2008. Antioxidant potential of solvents extract of Kappapycus alvarezii (Doty) Doty an edible seaweed. Food Chemistry 107 : 289-295.

Mabeau, S. and Fleurence, J. 1993. Seaweed in food products: bio-chemical and nutritional aspects. Trends in Food Science and Technology 4: 103-107.

McHugh. 2003. A guide To the Seaweed industry. FAO Fisheries Technical Paper. 441

Murdinah. 2007. Prospek pengembangan produk nori berbasis jenis-jenis rumput laut di Indonesia

Noya, E.D. 2015. Karakteristik nori berbahan dasar rumput laut merah Hypnea saidana. Skripsi. Fakultas Perikanan dan IImu Kelautan Universitas Pattimura.

Nurbahri,W. 2010. Analisis serat kasar http:'//wimvynurbahri.blogspot.com/2010/ 09/analisis-serat-kasar.html. Diakses November 2014

Shiokawa, K. 2008. Asakusa Nori. http;//www.tokyofoundation.org/en/topics /japanese-traditional-foods/vol-5asakusa-nori. Diakses : November 2014

Teddy, M. S. 2009. Pembuatan nori secara tradisional dari jenis rumput laut Gracillaria sp. Skripsi. Fakultas Perikanan dan IImu Kelautan. Institut Pertanian Bogor.

Waysima, Adawiyah, Dede, R. 2010. Evaluasi sensori (cetakan ke 5). Fakultas Teknologi Pertanian Institute Pertanian Bogor : Bogor 